\title{
Combining regenerative medicine strategies to provide durable reconstructive options: auricular cartilage tissue engineering
}

\author{
Zita M. Jessop ${ }^{1,2 \dagger}$, Muhammad Javed ${ }^{1,2 \dagger}$, Iris A. Otto ${ }^{3,4}$, Emman J. Combellack ${ }^{1,2}$, Siân Morgan ${ }^{1,2}$, \\ Corstiaan C. Breugem ${ }^{4}$, Charles W. Archer ${ }^{1}$, Ilyas M. Khan ${ }^{5}$, William C. Lineaweaver ${ }^{6}$, Moshe Kon ${ }^{4}$, Jos Malda ${ }^{3,7}$ \\ and lain S. Whitaker ${ }^{1,2^{*}}$
}

\begin{abstract}
Recent advances in regenerative medicine place us in a unique position to improve the quality of engineered tissue. We use auricular cartilage as an exemplar to illustrate how the use of tissue-specific adult stem cells, assembly through additive manufacturing and improved understanding of postnatal tissue maturation will allow us to more accurately replicate native tissue anisotropy. This review highlights the limitations of autologous auricular reconstruction, including donor site morbidity, technical considerations and long-term complications. Current tissue-engineered auricular constructs implanted into immune-competent animal models have been observed to undergo inflammation, fibrosis, foreign body reaction, calcification and degradation. Combining biomimetic regenerative medicine strategies will allow us to improve tissue-engineered auricular cartilage with respect to biochemical composition and functionality, as well as microstructural organization and overall shape. Creating functional and durable tissue has the potential to shift the paradigm in reconstructive surgery by obviating the need for donor sites.
\end{abstract}

\section{Introduction}

The combined efforts of cell biologists, material scientists, tissue engineers and reconstructive surgeons and associated converging technologies [1] in the 21st century have put us in an enviable position compared with our predecessors. Due to recent advances in regenerative medicine and additive manufacturing we are entering into an age where we have the potential to replace like with like', by improving the quality of engineered tissue with respect to biochemical composition and functionality, as well as microstructural organization and overall shape.

The importance of regenerative medicine as an emerging discipline is gaining worldwide recognition with a

\footnotetext{
* Correspondence: iainwhitaker@fastmail.fm

${ }^{\dagger}$ Equal contributors

${ }^{1}$ Reconstructive Surgery \& Regenerative Medicine Research Group, Swansea University Medical School, Room 509, ILS2, Swansea SA2 8SS, UK

${ }^{2}$ The Welsh Centre for Burns and Plastic Surgery, Morriston Hospital, Swansea SA6 6NL, UK

Full list of author information is available at the end of the article
}

predicted world market value ranging from $\$ 2$ to 500 billion per annum in 5-10 years [2]; and the assumed finite reservoir of future value has encouraged many countries to invest in this area of research. This value could be exceeded if the barriers to translation and commercialization were overcome. Current research in tissue engineering is geared towards elucidating the appropriate compositional elements (biomaterials, biomolecules and cell sources) as well as methods of assembly. To drive translation of innovative regenerative medicine treatment options to preclinical studies and clinical trials, clinicians need to embed themselves as an essential part of the multidisciplinary team.

One area within the field of plastic and reconstructive surgery that has the potential to benefit from recent advances in regenerative medicine and biomanufacture is auricular reconstructive surgery [3-7]. Abnormal appearance of the ears has a profound effect on selfconfidence, quality of life and psychosocial development 
[8-11], and even minor disfigurement can cause psychological distress. Although the need for total ear reconstruction is relatively rare (e.g. microtia 1-17:10,000 births [12]), partial ear reconstruction owing to acquired defects (trauma, burns or cancer occurs in >1:500 of the population) is more commonly required. Total autologous reconstruction, due to its physical and aesthetic prominence, features in the lay press disproportionately often; and from time to time trumpets standard methods of reconstruction that have been used for decades [13, 14]. At the same time, media coverage of scientific advances often leads patients to believe that three-dimensional printing of auricles lies around the next corner [15-18].

The first tissue-engineered, ear-shaped appendages made from bovine chondrocytes and biocompatible scaffolds by the Vacanti group were prone to deformation when xenografted onto immune-compromised mice, highlighting the lack of long-term stability [6]. We will use the lessons learnt from auricular cartilage tissue engineering to illustrate how combining additive manufacturing and regenerative medicine for tissue-engineering purposes can be used to create functional and durable tissue with potential to shift the paradigm in reconstructive surgery.

\section{Contemporary autologous auricular reconstruction}

The current gold standard of autologous auricular reconstruction is considered one of the most challenging operations in reconstructive surgery largely due to the complex three-dimensional anatomy [19]. The benchmark work by Tanzer, who was the first to describe the use of autologous costal cartilage to create a threedimensional auricular framework [20-22], has had a significant impact on current strategies. Subsequent work by Brent [23-28], Park [29, 30], Nagata [31-36] and Firmin [37] played a pivotal role in refinement of surgical techniques for ear reconstruction (Table 1). Two-stage total auricular reconstruction is now the standard treatment across the European Union and the United States [12]. The benefits of autologous auricular reconstruction compared with allogenic options such as silastic [38-40] or porous polyethylene (Medpor; Stryker, Kalmanzoo, MI, USA) [41-43] are high biocompatibility [44], longterm stability, immunocompatibility [5] and the ability to grow with the patient $[5,7,45]$.

To date, costal cartilage has proven to be the only source of cartilage with an adequate quantity, integrity and acceptable morbidity [46]. The auricular framework usually requires three to four costal cartilage segments, which can be harvested ipsilaterally or contralaterally [21, 47], providing an immunocompatible solution for restoration of the auricle. There have been various advances in the surgical approach to autologous auricular reconstruction; these include the transition towards single-stage procedures $[29,48,49]$, and the use of three-dimensional imaging $[50,51]$ and templates [52] to better match the native ear. The fundamental principles, however, have remained the same since Harold D. Gillies [53] was one of the first to use autologous rib cartilage for auricular reconstruction. The techniques provide consistently excellent results from experienced surgeons but are not without their limitations, creating a clinical need for a tissue-engineered solution.

\section{Limitations of current auricular reconstructive techniques}

Donor site morbidity

Although there is rich experience worldwide in cartilage harvest for auricular reconstruction, there is a relative

Table 1 Summary of total autologous auricular reconstructive techniques

\begin{tabular}{|c|c|c|c|}
\hline Surgeon & Technique & Pros & Cons \\
\hline Tanzer [20-22] & $\begin{array}{l}\text { Four stages: } \\
\text { 1. Rotation of the lobule into a transverse position } \\
\text { 2. Fabrication and placement of a costal } \\
\text { cartilage framework } \\
\text { 3. Elevation of the ear from the side of the head } \\
\text { 4. Construction of a tragus and conchal cavity }\end{array}$ & $\begin{array}{l}\text { - First stepwise total auricular } \\
\text { reconstruction } \\
\text { - Good results }\end{array}$ & $\begin{array}{l}\text { - Multiple operations } \\
\text { - Transposing lobule first } \\
\text { poses risk of vascular compromise } \\
\text { of skin flap [64] }\end{array}$ \\
\hline Brent [23-28] & $\begin{array}{l}\text { Four stages: } \\
\text { 1. Rib cartilage framework fabrication and placement } \\
\text { 2. Lobule transposition } \\
\text { 3. Elevation of framework and creation of a } \\
\text { retroauricular sulcus } \\
\text { 4. Conchal excavation and tragus construction }\end{array}$ & $\begin{array}{l}\text { - Good contour } \\
\text { - Postoperative drain limits } \\
\text { complications of bolster } \\
\text { dressings [64] }\end{array}$ & $\begin{array}{l}\text { - Multiple operations } \\
\text { - Lack definition of conchal bowl [64] } \\
\text { - Composite skin/cartilage tragal } \\
\quad \text { grafts can contract [37] }\end{array}$ \\
\hline Nagata [31-36] & $\begin{array}{l}\text { Two stages: } \\
\text { 1. Fabrication of costal cartilage framework } \\
\text { including the tragus, conchal excavation and } \\
\text { rotation of the lobule } \\
\text { 2. Elevation of framework, placement of cartilage } \\
\text { graft in auriculocephalic sulcus, covered with } \\
\text { temporoparietal fascial flap and skin graft }\end{array}$ & $\begin{array}{l}\text { - Less operations } \\
\text { - High-definition framework } \\
\text { to create a good tragus [64] }\end{array}$ & $\begin{array}{l}\text { - More cartilage needed } \\
\text { - Detailed framework so long learning curve } \\
\text { - Minimum age } 10 \text { years } \\
\text { - Partial necrosis of posterior flap [37] } \\
\text { - Wire sutures increase extrusion [37] }\end{array}$ \\
\hline
\end{tabular}


paucity of large series investigating donor site morbidity. Uppal et al. [54] reported on 42 patients and found that the most common problems were chest wall pain and clicking, whilst the most serious was a pneumothorax. Other authors have highlighted chest wall contour deformity as a complication, which can be a particular problem when using Nagata's technique [31-36] that requires the use of a greater amount of cartilage compared with the Brent technique [23-28]. This problem can be minimized by delaying rib cartilage harvest until patients are older ( $>10$ years of age) and leaving the perichondrium intact to allow regeneration of costal cartilage over time [55-59]. Despite these efforts, thoracic computed tomography with three-dimensional reconstruction confirms localized skeletal donor site deformities as late as 6 months after surgery [60]. Hypertrophic scarring is another complication that is particularly common in this group of patients [55, 61-63], although careful placement of surgical incisions can make them less obvious [64]. These surgical adaptations, although useful in reducing donor site morbidity, do not eliminate the problems altogether (Table 2).

\section{Long-term limitations of the reconstructed auricle}

The autologous costal cartilage used in traditional auricular reconstruction can calcify $[23,65]$ and become resorbed $[64,66,67]$ over time. This means that the reconstructed ear may become stiff or thickened [23, 65], with loss of projection or definition [37, 64, 66, 67] resulting in a variable final aesthetic result. The fibro- cartilaginous donor tissue is also intrinsically different in terms of flexibility and strength from the native elastic cartilage it aims to reconstruct [23, 64]. The close association of skin and cartilage in the ear can also render the dermal blood supply vulnerable during dissection and this may cause a relative ischaemia leading to constriction, which can further distort the intended shape [37]. Furthermore, skin flap necrosis or postoperative infections can lead to the rare but serious problem of extrusion $[28,36,37,64]$ (Table 3).

\section{Technical considerations}

The timing of total autologous auricular reconstruction is determined by the balance between availability of sufficient donor-site costal cartilage, usually adequate by age 6 , and avoiding psychosocial problems associated with peer perception when starting school between ages 5 and $6[19,21,68,69]$. The surgical techniques themselves are complex and involve shaping the harvested cartilage to match the contralateral ear either by eye, using image-acquisition technology [50, 51, 70] or via templates $[52,63]$. Consistently excellent results require a prolonged period of training to build up the expertise and experience from only a few world experts who have refined their techniques over many years [23-37, 62-64]. This development of expertise will become increasingly difficult with expanding trainee numbers in reconstructive surgery and the potential reduced training time, which will limit the availability of world-class results to the general population.

Table 2 Donor site morbidity associated with total autologous auricular reconstruction

\begin{tabular}{|c|c|c|c|c|}
\hline & Donor site morbidity & Incidence & Reference & Total number of patients per study \\
\hline \multirow[t]{5}{*}{ Early } & \multirow[t]{2}{*}{ Pneumothorax } & $3(1 \%)$ & \multirow[t]{2}{*}[56,57]{} & 270 \\
\hline & & $19(22 \%)$ & & 88 \\
\hline & \multirow[t]{2}{*}{ Atelectasis } & $4(22 \%)$ & \multirow[t]{2}{*}[55,57]{} & 18 \\
\hline & & $7(8 \%)$ & & 88 \\
\hline & Pleural effusion & - & [58] & - \\
\hline \multirow[t]{12}{*}{ Delayed } & Persistent pain & $6(14 \%)$ & {$[54]$} & 42 \\
\hline & Thoracic scoliosis & $4(25 \%)$ & [55] & 16 \\
\hline & Seroma & $9(8 \%)$ & [59] & 108, rhinoplasty group \\
\hline & Clicking & $3(7 \%)$ & [54] & 42 \\
\hline & \multirow[t]{5}{*}{ Abnormal scarring } & $0(0 \%)$ & \multirow[t]{5}{*}[54,57,61-63]{} & 42 \\
\hline & & $3(2.7 \%)$ & & 110 \\
\hline & & $12(14 \%)$ & & 88 \\
\hline & & $14(5.3 \%)$ & & 264 \\
\hline & & $21(6.5 \%)$ & & 322 \\
\hline & \multirow[t]{3}{*}{ Contour deformity } & $3(7 \%)$ & \multirow[t]{3}{*}[54,55,57]{} & 42 \\
\hline & & $16(50 \%)$ & & 32 \\
\hline & & $22(25 \%)$ & & 88 \\
\hline
\end{tabular}


Table 3 Long-term limitations of autologous auricular reconstruction

\begin{tabular}{ll}
\hline Long-term limitations & Reasons \\
\hline Stiffness & $\begin{array}{l}\text { 1. Different biomechanical } \\
\text { properties of fibrocartilage } \\
\text { donor [23] } \\
\text { 2. Heterotopic calcification } \\
\text { [23,65] }\end{array}$ \\
\end{tabular}

Extrusion

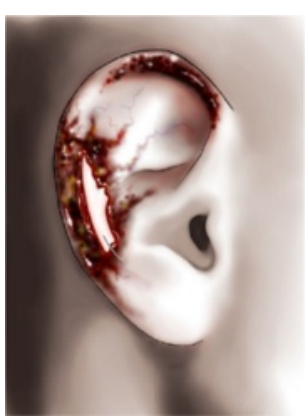

1. Skin flap necrosis [37]

2. Wire sutures to assemble cartilage framework $[36,37]$ 3. Wound infection or pressure dressings $[28,64]$

Projection loss

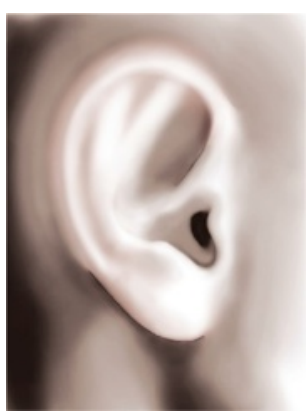

Distortion

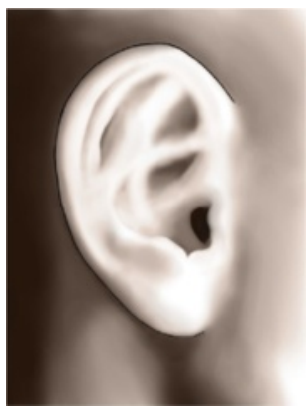

\section{Auricular reconstruction combining regenerative medicine and additive manufacturing}

Over the past decade there has been an incremental expansion of the applications of tissue-engineering technology to reconstructive surgery. Historically, tissue engineering has involved cell culture techniques, cell seeding of scaffolds to mimic extracellular matrix and growth of tissue in a bioreactor. These approaches have attempted to generate durable auricular cartilage replacements matching the functional and aesthetic properties of normal ears $[6,7,45,71-74]$. Although progress has been made and techniques have been refined, it is not yet possible to mimic the functional characteristics of native ears (flexibility, strength and elasticity) whilst maintaining the correct shape of the ear after insertion under the skin for prolonged periods of time $[6,75]$.

The heterogeneity in approaches indicates that we do not yet have a long-lasting tissue-engineered solution. A number of limitations have been identified with current tissue-engineered auricular cartilage, as outlined in Fig. 1. Constructs implanted into immune-competent animal models have been observed to undergo inflammation, fibrosis [75] and foreign body reaction [76]. This is particularly problematic with polymeric scaffolds, such as poly(lactic acid) or poly(glycolic acid) scaffolds, whose degradation products promote antigenicity [77]. In many cases, the unrelated cell sources produce immature neocartilage that is prone to degradation $[6,78]$, is prone to calcification $[5,79]$ and is easily breakable [80-82].

Lessons from tracheal tissue engineering indicate that constructs from non-related stem cell sources combined with synthetic scaffolds have their limitations [83-85]. This suggests that simply combining the building blocks for tissue engineering is not sufficient for true regeneration. Observations in developmental biology have shown that function follows form [86], and in order to create true 'like for like' tissue for reconstructive surgery it is important to accurately reproduce native tissue anisotropy [87]. In the case of auricular cartilage, the ideal scenario consists of the right compositional elements: such as tissue-specific (auricular cartilage) stem cells, non-immunogenic scaffolds, the correct method of assembly to replicate the native microenvironment and biological induction of maturation using growth factors (Table 4).

Successful translation of tissue engineering for any type of reconstruction will require significant infrastructure and scale-up technology. The most commercially viable and widespread use is likely to come from 'off the shelf' tissue-engineered products. Clinical grade processing, scale-out and commercialization all incur substantial time and cost. It is important for clinicians to have a working knowledge of these barriers to translation. These barriers, however, are not unique to tissue engineering; 


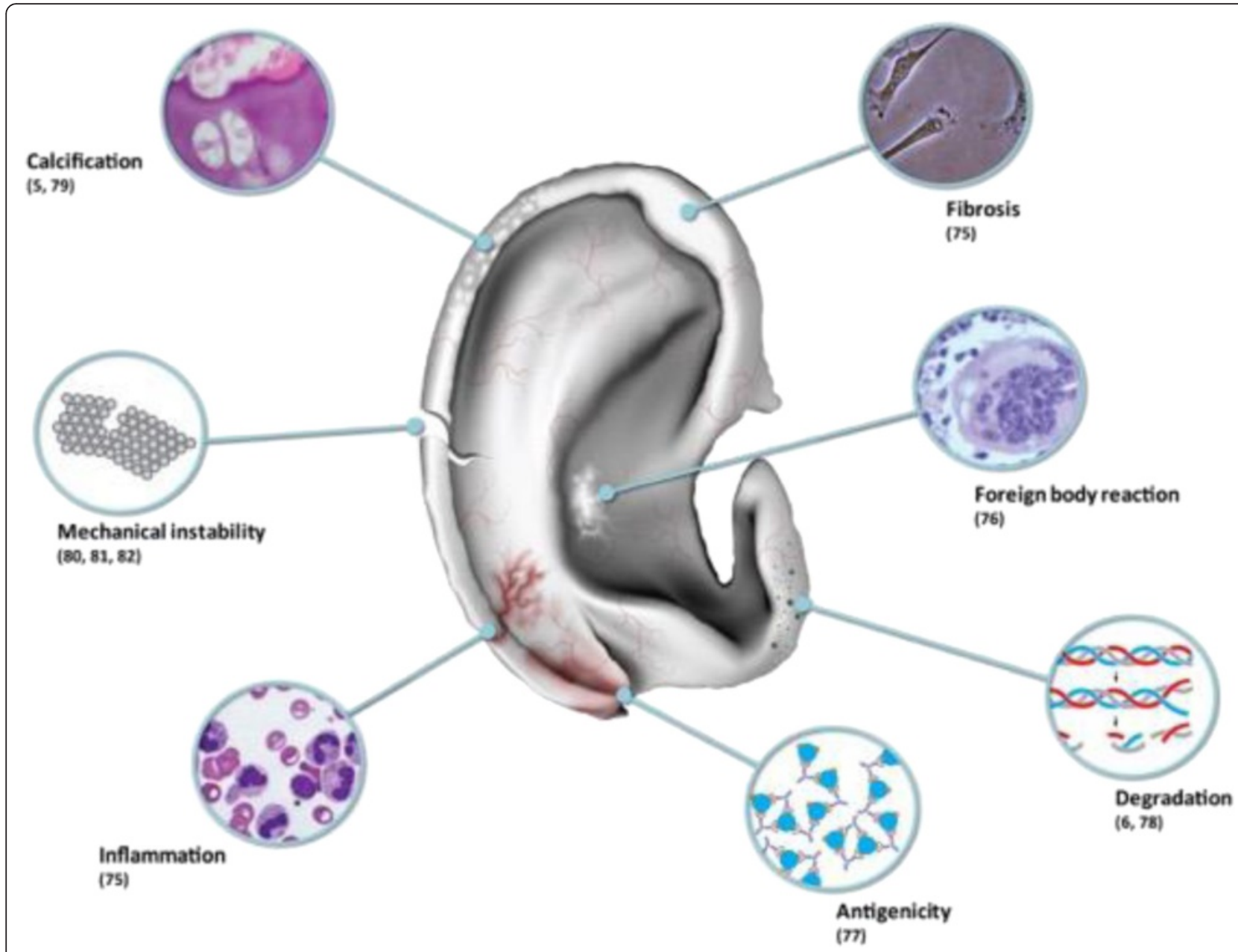

Fig. 1 Limitations of current tissue-engineered auricular cartilage constructs

many countries have large translational income streams following successful engagement with large biotech companies with streamlined regulatory processes [88].

\section{Tissue-specific stem cell utilization}

For complex three-dimensional composite tissues such as the ear, it is still unknown how to sufficiently engage and enhance the body's own repair processes to regenerate lost tissue. The complexity, in this case, must be engineered. To regenerate auricular structures faithfully using extrinsic mechanisms, we need to use biocompatible scaffolds that are populated by auricular chondrocytes which in conductive environments will produce elastic cartilage. In the current paradigm, the cellular

Table 4 Potential future benefits and challenges of combining regenerative medicine with additive manufacturing

\begin{tabular}{|c|c|c|c|}
\hline & Feature & Benefits & Challenges \\
\hline \multirow[t]{3}{*}{ Bioprinting } & $\begin{array}{l}\text { Control over macrostructure and } \\
\text { microstructure of tissue produced }\end{array}$ & $\begin{array}{l}\text { Replicate anatomical formReduce surgical } \\
\text { technique learning curve }\end{array}$ & $\begin{array}{l}\text { Biomechanical properties of bioinksEffect } \\
\text { of printing on cellsPrinting resolution }\end{array}$ \\
\hline & $\begin{array}{l}\text { Patient-specific macrostructure from } \\
\text { image acquisition (CT/MRI) }\end{array}$ & Reduce variability in surgical outcomes & $\begin{array}{l}\text { Macrostructure may alter during } \\
\text { bioreactor maturation }\end{array}$ \\
\hline & Manufacture ex vivo & Avoid donor site morbidityReduce operating time & $\begin{array}{l}\text { Potential for contaminationRegulatory } \\
\text { constraints }\end{array}$ \\
\hline \multirow[t]{2}{*}{$\begin{array}{l}\text { Regenerative } \\
\text { medicine }\end{array}$} & $\begin{array}{l}\text { Tissue-specific stem cells to improve } \\
\text { quality and functionality of } \\
\text { engineered tissue }\end{array}$ & $\begin{array}{l}\text { True 'like for like' replacementRestoring native } \\
\text { anisotropy allows improved matching of } \\
\text { mechanical properties }\end{array}$ & $\begin{array}{l}\text { Genetic stability and differentiation } \\
\text { capacity of cells after prolonged } \\
\text { expansion in culture }\end{array}$ \\
\hline & $\begin{array}{l}\text { Tissue maturation utilizing growth } \\
\text { factors }\end{array}$ & Reduce degradation and constriction & $\begin{array}{l}\text { Optimal growth factor combinations and } \\
\text { temporal effects }\end{array}$ \\
\hline
\end{tabular}


component is derived from stem cells that are induced to continually renew and that when directed have the potential to differentiate into chondrocytes and make cartilage. Several groups have used bone marrow-derived stem cells [89-92], adipose-derived stem cells [93-95] and blood-acquired mesenchymal progenitors [96] to various degrees of efficacy. Observations in developmental biology indicate that, for true 'like for like' replacement, tissue-specific stem cell sources are needed. Chondroprogenitors were first identified in articular cartilage $[97,98]$, and more recently it has been shown that they can also be found in the perichondral layer of auricular cartilage [99-101]. Chondroprogenitors from this layer have the power to proliferate for many generations, producing hundreds of millions of progeny from a single founder cell whilst retaining the capacity to differentiate into auricular chondrocytes and make elastic cartilage [100-102]. A further advantage of using auricularspecific stem cells is that they are able to reconstitute both the perichondrium and chondrium, and thus other functions, such as the ability to produce and react to tissue-specific developmental cues in order to regulate normal growth over the lifetime of an implant. Studies show that using highly related cell sources such as articular, costal and naso-septal chondrocytes, unlike those derived from the auricle itself [103], does not result in production of elastin-containing cartilage which has important physiological and biomechanical consequences $[79,104,105]$. For example, costal cartilage, which is the mainstay of autologous auricular reconstruction [19], eventually forms calcified cartilage following its normal developmental pathway [106-108] and, although more common in old age, calcifications can be encountered in young adults as well [106].

\section{Maturation process}

Whilst tissue-specific stem cells ensure the production of auricular cartilage, the neo-cartilaginous structure formed is immature in phenotype. Immature cartilage is highly active metabolically as it grows and develops, and this tissue in a mature organism may be liable to resorption. In the landmark study of auricular tissue engineering by the Vacanti group, tissue-engineered, ear-shaped appendages made from bovine chondrocytes and biocompatible scaffolds were xenografted into immunecompromised mice [6]. The implanted constructs were initially supported by externally fixed stents, and once the stents were removed the shape of the constructs eventually deformed and shrank. This observation highlights often-overlooked features of tissue-engineered implants, the lack of long-term biochemical and biomechanical stability. These experiments also suggest that susceptibility to resorption may be an intrinsic property of neo-cartilage, as well as resulting from the activity of extrinsic factors, for example inflammatory mediators, following implantation. An internal permanent support, such as a coiled wire, although shown to reduce shrinkage of the tissue-engineered auricle in animal models [109], fails to overcome the recognized complications, particularly extrusion, of implanted synthetic materials [38-40, 42, 43, 110].

The collagen and elastin framework of the native ear can last for an entire lifetime, partly due to extensive chemical cross-linking that over time stabilizes these structural fibres. The process of cross-linking occurs during postnatal maturation providing biochemical heterogeneity [111, 112]. Using the example of articular cartilage, it is a functional adaptation response [78] and in humans may take up to 15 years to become complete [111]. Changes in collagen cross-linking correlate with biomechanical strength of cartilage [113], a recognized yet underused outcome measure of durable tissueengineered cartilage $[5,114]$. The extended time required for maturation and the fact that certain elements of this process require temporally encoded developmental cues may be the root cause for the failure of intrinsic mechanisms of cartilage repair following injury. The lack of maturation is without doubt a major cause of the failure of implanted tissue-engineered cartilage to provide durable replacement tissue for focal lesions in articular cartilage. However, recent work by Khan et al. $[115,116]$ shows that it may be possible to create implants containing mature cartilage, whose structure and function mimics that of surrounding cartilage, with potential to be resilient to resorption. Their work on native cartilage explants has shown that postnatal maturation can be precociously induced by growth factors fibroblast growth factor (FGF)-2 and transforming growth factor beta-1 (TGF-B1) in immature articular cartilage. Growth factortreated immature tissue is stiff and smooth and is morphologically as well as biochemically indistinguishable from native adult mature cartilage. There is also evidence that FGF supplementation improves the quality of tissue-engineered elastic neo-cartilage from expanded human auricular chondrocytes [117]. Consequently, a major question that requires our attention is: to what extent does auricular cartilage undergo tissue maturation? Our preliminary work has shown that there are clear morphological differences between mature and immature bovine ears (Fig. 2). By understanding the dynamics of maturational processes in auricular cartilage that underpin these morphological differences, we have the potential to highly accelerate the fabrication of implantable replacement tissues that are both functional and durable.

Nevertheless, the cost-effective production of a scalable solution for craniofacial cartilage replacement tissues, at least in the near term (5-10 years), will require 

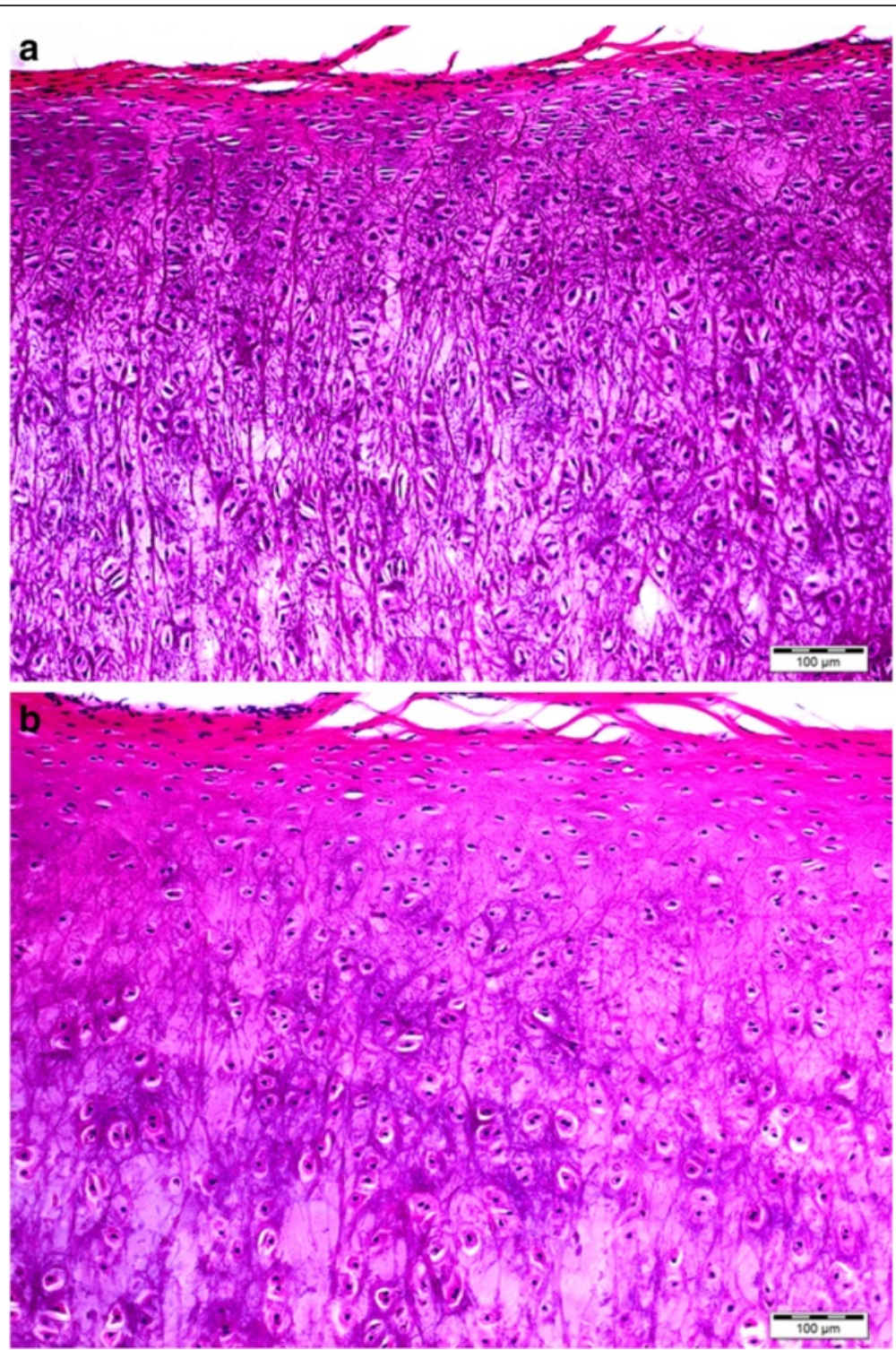

Fig. 2 Histology of bovine auricular cartilage (haematoxylin and eosin staining). a Immature bovine auricular cartilage demonstrating homogeneous cell organization and high cell density. b Mature bovine auricular cartilage showing depth-dependent cell density and organization

the implantation of allograft material. We are fortunate in this regard that cartilage is immunoprivileged, being avascular, alymphatic and aneural and surrounded by a dense extracellular matrix that is impervious to leukocytes $[118,119]$. However, before allogenic constructs become a viable option, human trials are essential to confirm the preliminary in vitro and animal work. Chondrocytes in cartilage rely solely on diffusion to obtain their nutrients and disperse their waste products, and for these reasons it is likely that fabricated implants which are stabilized through growth factor-induced maturation prior to implantation will last the lifetime of the patient.

\section{Three-dimensional bioprinting}

Three-dimensional printing creates objects from a digital model in a layer-by-layer fashion. As such, it offers full control over internal and external architecture of the object, in contrast to subtractive manufacturing approaches. Three-dimensional printing is dramatically altering the way we perceive manufacturing and is an important driving force of the paradigm shift towards digital manufacturing that is now often regarded as the third industrial revolution [120]. In reconstructive surgery, this technology already enables fabrication of patient-specific models for preoperative planning (e.g. autologous free flap reconstruction [121]), patient or surgeon education [122] or 
intraoperative use (e.g. mandibular [123] or breast [124] reconstruction). Moreover, customized implants to restore anatomical features have also been produced, including partial or complete mandibular replacements $[125,126]$ and cranial constructs [127, 128].

Degradable implants with overhang geometries and internal cavities can be created by the inclusion of temporal support structures from polymers [129-131] (Fig. 3). These scaffolds can then be inoculated with cells. On the other hand, three-dimensional printing can also yield patient-specific moulds in which cell-containing hydrogels can subsequently be cast to obtain implants with complex shapes; for example, for potential restoration of auricular deformities [73, 132]. Nevertheless, these approaches only yield relatively homogeneous constructs and lack the control over specific placement in three dimensions of different biomaterials, cells or other bioactive components, such as growth factors to stimulate specific cellular differentiation.
Three-dimensional bioprinting entails the creation of biological structures for tissue engineering, pharmacokinetic or basic cell biology studies (including disease models) by a computer-aided transfer process for patterning and assembling living and non-living materials with a prescribed three-dimensional organization [133-135]. Hydrogels are widely used as bioinks (i.e. printable biological materials), since they can recapitulate a number of features of the native extracellular matrix and allow cell encapsulation in a highly hydrated three-dimensional environment [136-139]. Biofabrication, using robotic dispensing for example, imposes opposing requirements on the hydrogel materials [51, 133, 140, 141]. Biofabrication of complex structures, such as the auricle, requires a stiff hydrogel for high resolution and mechanical stability on implantation whilst being soft enough to allow cellular migration, proliferation and differentiation. Co-depositing thermoplastic polymer fibres and cell-laden hydrogels can be used to reinforce and hence tailor the mechanical
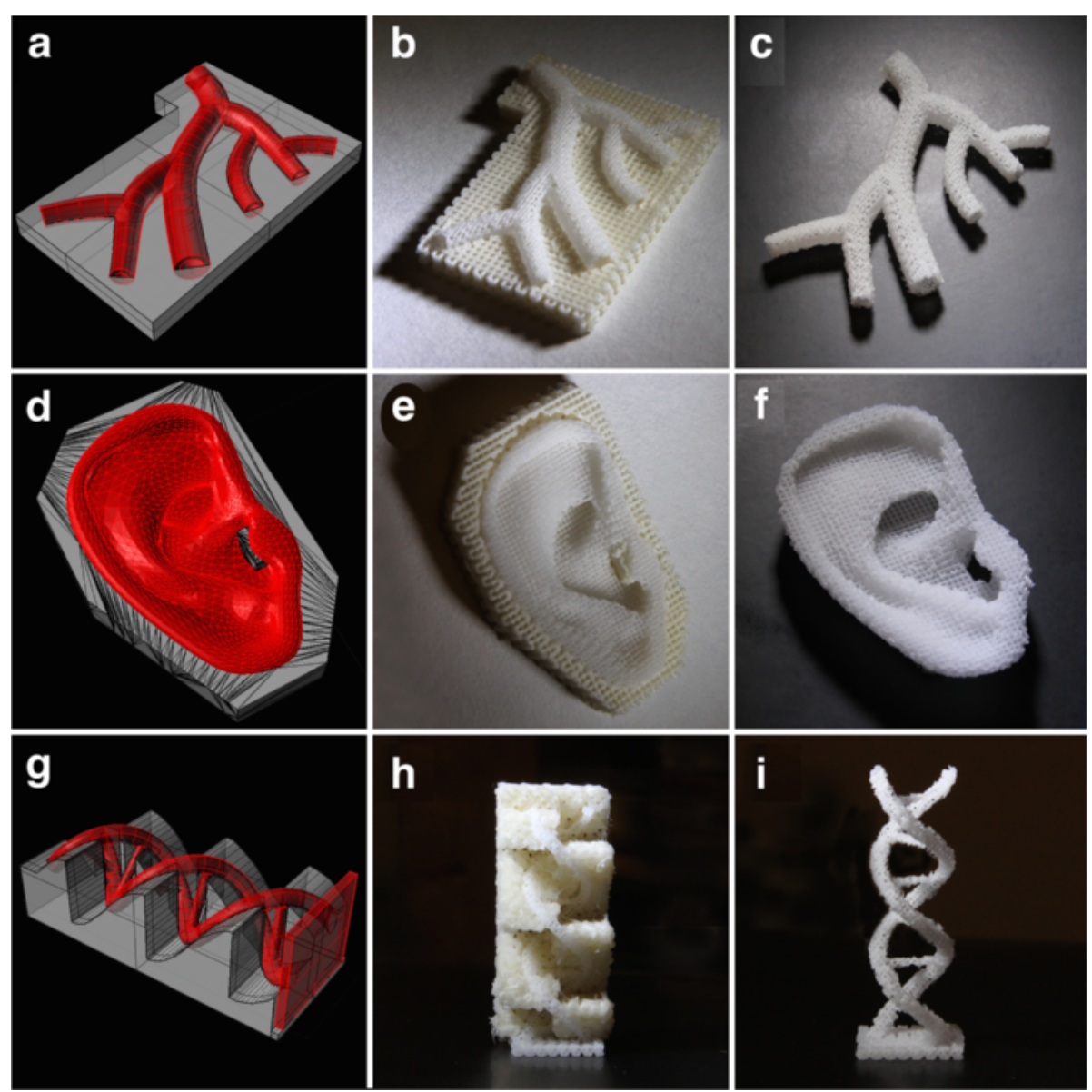

Fig. 3 Three-dimensional-printed complex anatomical structures based on polycaprolactone (PCL) with polyvinyl alcohol (PVA) support. a-c Vascular tree. $\mathbf{d}-\mathbf{f}$ Right ear. $\mathbf{g}-\mathbf{i}$ DNA helix. a, d, $\mathbf{g}$ Computer-aided designs showing permanent (red) and sacrificial (grey) components. b, e, $\mathbf{h}$ Printed structures showing PCL (bright white) and PVA (off-white). d, f, i PCL scaffold after sacrificing PVA support. Reproduced with permission from Visser et al. [131] and Institute of Physics Publishing 
properties of the constructs $[138,142]$, offering the opportunity to support the long-term maintenance of the implant shape. A more biological approach using in vitro maturation, as already described, could increase construct stiffness via specific tissue matrix deposition $[115,116]$, although high cell concentrations and a reasonable preculturing period would be required. The future advantage offered by three-dimensional bioprinting is biofabrication of more complex structures such as auricular cartilage with an overlying skin and soft tissue envelope due to multiple 'bioinks' containing differing cell and hydrogel types.

\section{Conclusion}

Auricular reconstruction is an ideal example of how refinement in surgical techniques over many years can give excellent results in expert hands. However, as with any autologous technique, auricular reconstruction is limited by donor site morbidity. Recent advances in bioengineering and collaborations between stem cell biologists, engineers and clinicians have developed a landscape which provides the opportunity to engineer auricular cartilage constructs that resemble the human ear in shape, size and flexibility.

There are fundamental scientific questions that need to be addressed in order to overcome the current limitations of tissue-engineered constructs for long-term sustainability, including optimizing utilization of tissue-specific stem cells and manipulation of maturation. We have used the auricle as an exemplar to illustrate how combining regenerative medicine with three-dimensional bioprinting has the potential to create custom-made tissue-engineered solutions which obviates the need for a donor site, representing a paradigm shift in reconstructive surgery. It is, however, important to recognize that there are a number of barriers to successful translation which need to be overcome before tissue-engineered products become a commercially viable and widespread alternative to autologous reconstruction.

\section{Abbreviations \\ FGF: Fibroblast growth factor; TGF- $\beta 1$ : Transforming growth factor beta-1.}

\section{Competing interests}

The authors declare that they have no competing interests.

\section{Authors' contributions}

ZMJ performed a comprehensive literature search, contributed ideas and drafted the manuscript. MJ, EJC and SM were involved in assimilating data and drafting the manuscript. IMK contributed data and critically revised sections of the manuscript. CWA, MK, JM and WCL contributed ideas and critically revised the manuscript. IAO and $C C B$ critically revised the manuscript. ISW conceived the study, contributed ideas and critically revised the manuscript. All authors read and approved the final manuscript and agree to be accountable for all aspects of the work.

\section{Acknowledgments}

The authors would like to thank the Medical Research Council and Royal College of Surgeons for funding this work, Professor Steve Bain and ABM
University Health Board for funding and ongoing support, as well as Mr Stephen Atherton RMIP MIMI for the illustrations.

\section{Author details}

${ }^{1}$ Reconstructive Surgery \& Regenerative Medicine Research Group, Swansea University Medical School, Room 509, ILS2, Swansea SA2 8SS, UK. ${ }^{2}$ The Welsh Centre for Burns and Plastic Surgery, Morriston Hospital, Swansea SA6 6NL, UK. ${ }^{3}$ Department of Orthopaedics, University Medical Center Utrecht, Utrecht 3584 CX, The Netherlands. ${ }^{4}$ Department of Plastic and Reconstructive Surgery, University Medical Center Utrecht, Utrecht, The Netherlands. ${ }^{5}$ KhanLab, Swansea University, ILS2, Swansea SA2 8SS, UK. ${ }^{6}$ Division of Plastic Surgery, University of Mississippi Medical Center, Jackson, Mississippi 39216, USA. 'Department of Equine Sciences, Faculty of Veterinary Medicine, Utrecht University, Domplein 29, 3512 JE Utrecht, The Netherlands.

Published online: 28 January 2016

\section{References}

1. Moroni L, Hamann D, Paoluzzi L, Pieper J, de Wijn JR, van Blitterswijk CA. Regenerating articular tissue by converging technologies. PLoS One. 2008;3(8):e3032.

2. Biophoenix. Opportunities in stem cell research and commercialisation. London: Business Insights; 2006. p. 80.

3. Togo T, Utani A, Naitoh M, Ohta M, Tsuji Y, Morikawa N, et al. Identification of cartilage progenitor cells in the adult ear perichondrium: utilization for cartilage reconstruction. Lab Invest. 2006;86(5):445-57.

4. Ruszymah BHI, Lokman BS, Asma A, Munirah S, Chua K, Mazlyzam AL, et al. Pediatric auricular chondrocytes gene expression analysis in monolayer culture and engineered elastic cartilage. Int J Pediatr Otorhinol. 2007;71(8):1225-34.

5. Bichara DA, O'Sullivan NA, Pomerantseva I, Zhao X, Sundback CA, Vacanti JP, et al. The tissue-engineered auricle: past, present, and future. Tissue Eng Part B Rev. 2012;18:51-61.

6. Cao Y, Vacanti JP, Paige KT, Upton J, Vacanti CA. Transplantation of chondrocytes utilizing a polymer-cell construct to produce tissue-engineered cartilage in the shape of a human ear. Plast Reconstr Surg. 1997;100:297-302.

7. Haisch A, Klaring S, Groger A, Gebert C, Sittinger M. A tissue-engineering model for the manufacture of auricular-shaped cartilage implants. Eur Arch Otorhinolaryngol. 2002:259:316-21.

8. Horlock N, Vögelin E, Bradbury E, Grobbelaar AO, Gault DT. Psychosocial outcome of patients after ear reconstruction: a retrospective study of 62 patients. Ann Plast Surg. 2005;54(5):517-24.

9. Jiamei D, Jiake C, Hongxing Z, Wanhou G, Yan W, Gaifen L. An investigation of psychological profiles and risk factors in congenital microtia patients. J Plast Reconstr Aesthet Surg. 2008;61:S37-43.

10. Lourenco Gasques JA, JM P d G, Navarro Cruz EMT. Psychosocial effects of otoplasty in children with prominent ears. Aesth Plast Surg. 2008;32:910-4.

11. Steffen A, Magritz R, Frenzel H, Edwards T, Siegert R. Psychometric validation of the youth quality of life-facial differences questionnaire in patients following ear reconstruction with rib cartilage in microtia. Plast Reconstr Surg. 2012;129(1):184e-6e.

12. Luquetti DV, Leonicini E, Mastroiacovo P. Microtia-anotia: a global review of prevalence rates. Birth Defects Res A Clin Mol Teratol. 2011;91:813-22.

13. Evans $K$. The remarkable surgery that enabled doctors to use cartilage from 10-year-old Olivia's rib to give her a new ear. 31 Dec 2011. http://www.dailymail.co.uk/health/article-2080722/The-remarkablesurgery-enabled-doctors-use-cartilage-10-year-old-Olivias-rib-new-ear.html. Accessed 6 Nov 2014.

14. Walsh F. Boy has ears created from ribs. 11 Aug 2014. http://www.bbc.co. uk/news/health-28746868. Accessed 6 Nov 2014.

15. Naik G. Science fiction comes alive as researchers grow organs in lab. 22 Mar 2013. http://www.wsj.com/news/articles/SB10001424127887323699704 578328251335196648?mg=reno64-wsj\&url=http\%3A\%2F\%2Fonline.wsj. com\%2Farticle\%2FSB10001424127887323699704578328251335196648.html. Accessed 2 Dec 2014.

16. Dunham M. Britain makes a multimillion-dollar push towards lab-grown organs. 8 Apr 2014. http://www.nydailynews.com/life-style/health/nosesears-blood-vessels-grow-britain-article-1.1749917. Accessed 2 Dec 2014.

17. Weller C. Scientists use stem cells to grow body parts in their lab, including noses, ears, and tear ducts. 8 Apr 2014. http://www.medicaldaily.com/ 
scientists-use-stem-cells-grow-body-parts-their-lab-including-noses-ears-andtear-ducts-275122. Accessed 2 Dec 2014.

18. Massey N. Doctors creating human ears using 3D printers hope to help children across the world. 5 Oct 2014. http://www.mirror.co.uk/news/uknews/doctors-creating-human-ears-using-4382408. Accessed 2 Dec 2014.

19. Sivayoham $\mathrm{E}$, Woolford TJ. Current opinion on auricular reconstruction. Curr Opin Otolaryngol Head Neck Surg. 2012;20(4):287-90.

20. Tanzer RC. Total reconstruction of the external ear. Plast Reconstr Surg. 1959;23:1

21. Tanzer RC. Total reconstruction of the auricle: the evolution of a plan of treatment. Plast Reconstr Surg. 1971;47:523.

22. Tanzer RC. Microtia: a long-term follow-up of 44 reconstructed auricles. Plast Reconstr Surg. 1978;61:161.

23. Brent B. Technical advances in ear reconstruction with autogenous rib cartilage grafts: personal experience with 1200 cases. Plast Reconstr Surg. 1999;104:319.

24. Brent B. The correction of microtia with autogenous cartilage grafts II: atypical and complex deformities. Plast Reconstr Surg. 1980;66:13.

25. Brent B. The correction of microtia with autogenous cartilage grafts I: the classic deformity. Plast Reconstr Surg. 1980;66:1.

26. Brent B, Byrd HS. Secondary ear reconstruction with cartilage grafts covered by axial, random, and free flaps of temporoparietal fascia. Plast Reconstr Surg. 1983;72:141.

27. Brent B. Modification of the stages in total reconstruction of the auricle: Parts I to IV (Discussion). Plast Reconstr Surg. 1994;93:267.

28. Brent B. Auricular repair with autogenous rib cartilage grafts: two decades of experience with 600 cases. Plast Reconstr Surg. 1992;90:355.

29. Park C, Lee TJ, Shin KS, et al. A single-stage two-flap method of total ear reconstruction. Plast Reconstr Surg. 1991;88:404.

30. Park C, Chung S. A single-stage two-flap method for reconstruction of partial auricular defect. Plast Reconstr Surg. 1998;102(4):1175-81.

31. Nagata S. A new method of total reconstruction of the auricle for microtia Plast Reconstr Surg. 1993;92:187-201.

32. Nagata S. Modification of the stages in total reconstruction of the auricle: part I. Grafting the three-dimensional costal cartilage framework for lobule-type microtia. Plast Reconstr Surg. 1994;93:221.

33. Nagata S. Modification of the stages in total reconstruction of the auricle: part II. Grafting the three-dimensional costal cartilage framework for concha-type microtia. Plast Reconstr Surg. 1994;93:231.

34. Nagata S. Modification of the stages in total reconstruction of the auricle: part III. Grafting the three-dimensional costal cartilage framework for small concha-type microtia. Plast Reconstr Surg. 1994;93:243.

35. Nagata S. Modification of the stages in total reconstruction of the auricle: part IV. Ear elevation. Plast Reconstr Surg. 1994;93:254.

36. Nagata S. Microtia: auricular reconstruction. In: Vanderkolk CA, editor. Plastic surgery: indications, operations, and outcomes, vol. 2. St. Louis, MO: Mosby; 2000. p. 1023-56.

37. Firmin F. Ear reconstruction in cases of typical micro-tia: personal experience based on 352 microtic ear corrections. Scand J Plast Reconstr Surg Hand Surg. 1998;32:35.

38. Cronin TD. Use of a silastic frame for total and subtotal reconstruction of the external ear: preliminary report. Plast Reconstr Surg. 1966;37:399.

39. Cronin TD, Greenberg RL, Brauer RO. Follow-up study of silastic frame for reconstruction of external ear. Plast Reconstr Surg. 1968;42:522.

40. Cronin TD, Ascough BM. Silastic ear construction. Clin Plast Surg. 1978;5:367

41. Wellisz T. Reconstruction of the burned external ear using a Medpor porous polyethylene pivoting helix framework. Plast Reconstr Surg. 1993;91(5):811-8.

42. Reinisch J. Microtia reconstruction using a polyethylene implant: an eight year surgical experience. Paper presented at the 1999 Annual Meeting of the American Association of Plastic Surgeons; 1999 May 5; Colorado Springs, CO.

43. Reinisch JF, Lewin S. Ear reconstruction using a porous polyethylene framework and temporoparietal fascia flap. Facial Plast Surg. 2009;25(3):181-9.

44. Isogai $N$, Kusuhara H, Ikada $Y$, Ohtani H, Jacquet R, Hillyer J, et al. Comparison of different chondrocytes for use in tissue engineering of cartilage model structures. Tissue Eng. 2006;12:691-703.

45. Shieh SJ, Terada S, Vacanti JP. Tissue engineering auricular reconstruction: in vitro and in vivo studies. Biomaterials. 2004;25:1545-57.
46. Siegert R, Magritz R. Reducing the morbidity involved in harvesting autogenous rib cartilage. Facial Plast Surg. 2009;25:169-74.

47. Fukuda O, Yamada A. Reconstruction of the microtic ear with autogenous cartilage. Clin Plast Surg. 1978;5(3):351-66.

48. Avelar JM, Psillakis JM. Microtia: total reconstruction of the auricle in one single operation. Br J Plast Surg. 1981;34(2):224-7.

49. Song $Y$, Song $Y$. An improved one-stage total ear reconstruction procedure. Plast Reconstr Surg. 1983;71:615.

50. Park G, Wiseman JB, Clark W. Correction of congenital microtia using stereolithography for surgical planning. Plastic Reconstr Surg. 2000;105(4):1444-7.

51. Nimeskern L, Feldmann EM, Kuo W, Schwarz S, Goldberg-Bockhorn E, Dürr $S$, et al. Magnetic resonance imaging of the ear for patient-specific reconstructive surgery. PLoS One. 2014;9(8):e104975.

52. Chen ZC, Chen PK, Hung KF, Lo LJ, Chen YR. Microtia reconstruction with adjuvant 3-dimensional template model. Ann Plast Surg. 2004;53(3):282-7.

53. Gillies H. Plastic surgery of the face. London: H. Frowde, Hodder \& Sougton; 1920

54. Uppal RS, Sabbagh W, Chana J, Gault DT. Donor-site morbidity after autologous costal cartilage harvest in ear reconstruction and approaches to reducing donor-site contour deformity. Plast Reconstr Surg. 2008;121(6):1949-55.

55. Ohara K, Nakamura K, Ohta E. Chest wall deformities and thoracic scoliosis after cartilage graft harvesting. Plast Reconstr Surg. 1997;99:1030-6.

56. Nagamizu H, Nagata S. Minimization of postoperative complications and problems at the donor site after costal cartilage resection. In: Harii K, editor. Plastic, reconstructive, and aesthetic surgery. Amsterdam: Kugler Publications; 1995. p. 423-4.

57. Thomson HG, Kim TY, Ein SH. Residual problems in chest donor sites after microtia reconstruction: a long-term study. Plast Reconstr Surg. 1995:95(6):961-8.

58. Kim YH, Namkung J, Lim BG, Min SH, Shin HW, Lim CH. Pleural effusion after microtia reconstructive surgery - a case report. Korean J Anesthesiol. 2011;61(2):166-8.

59. Moon BJ, Lee HJ, Jang YJ. Outcomes following rhinoplasty using autologous costal cartilage. Arch Facial Plast Surg. 2012;14(3):175-80.

60. Wallace CG, Mao HY, Wang CJ, Chen YA, Chen PK, Chen ZC. Three-dimensional computed tomography reveals different donor-site deformities in adult and growing microtia patients despite total subperichondrial costal cartilage harvest and donor-site reconstruction. Plast Reconstr Surg. 2014;133(3):640.

61. Zhang $Q$, Zhang R, Xu F, Jin P, Cao Y. Auricular reconstruction for microtia: personal 6-year experience based on 350 microtia ear reconstructions in China. Plast Reconstr Surg. 2009;123:849-58.

62. Osorno G. Autogenous rib cartilage reconstruction of congenital ear defects: report of 110 cases with Brent's technique. Plast Reconstr Surg. 1999;104(7):1951-64

63. Osorno G. A 20-year experience with the Brent technique of auricular reconstruction: pearls and pitfalls. Plast Reconstr Surg. 2007;119(5):1447-63.

64. Walton RL, Beahm EK. Auricular reconstruction for microtia: Part II. Surgical techniques. Plast Reconstr Surg. 2002;110:234-49.

65. Hiroki M, Tanaka K, Umeda T, Hata Y. Ear reconstruction in elderly patients: a two-part helix method in a framework. Br J Plast Surg. 2002;55(7):589-91.

66. Berghaus A, Toplak F. Surgical concepts for reconstruction of the auricle. Arch Otolaryngol Head Neck Surg. 1986;112:388-97.

67. Fischer $H$, Gubisch $W$, Sinha V. Auricular reconstruction-our experience at marienhospital stuttgart, Germany. Indian J Otolaryngol Head Neck Surg. 2010;62(2):162-7.

68. Beahm EK, Walton RL. Auricular reconstruction for microtia: Part I. Anatomy, embryology, and clinical evaluation. Plast Reconstr Surg. 2002;109(7):2472-82.

69. Kawanabe Y, Nagata S. A new method of costal cartilage harvest for auricular reconstruction: part I. Avoidance and prevention of intraoperative and postoperative complications and problems. Plast Reconstr Surg. 2006;117:2011-8

70. Schubert O, Sartor K, Forsting M, Reisser C. Three-dimensional computed display of otosurgical operation sites by spiral CT. Neuroradiology. 1996;38(7):663-8.

71. Britt JC, Park SS. Autogenous tissue-engineered cartilage: evaluation as an implant material. Arch Otolaryngol Head Neck Surg. 1998;124:671-7. 
72. Rodriguez A, Cao YL, Ibarra C, Pap S, Vacanti M, Eavey RD, et al. Characteristics of cartilage engineered from human pediatric auricular cartilage. Plast Reconstr Surg. 1999;103:1111-9.

73. Reiffel AJ, Kafka C, Hernandez KA, Popa S, Perez JL, Zhou S, et al. High-fidelity tissue engineering of patient-specific auricles for reconstruction of pediatric microtia and other auricular deformities. PLoS One. 2013;8(2):e56506.

74. Nimeskern L, van Osch GJVM, Müller R, Stok KS. Quantitative evaluation of mechanical properties in tissue-engineered auricular cartilage. Tissue Eng Part B Rev. 2013;20(1):17-27.

75. Kamil SH, Vacanti MP, Aminuddin BS, Jackson MJ, Vacanti CA, Eavey RD. Tissue engineering of a human sized and shaped auricle using a mold. Laryngoscope. 2004;114:867.

76. Christophel JJ, Chang JS, Park SS. Transplanted tissue-engineered cartilage. Arch Facial Plast Surg. 2006;8(2):117-22.

77. Nayyer L, Patel KH, Esmaelli A. Tissue engineering: revolution and challenge in auricular cartilage reconstruction. Plast Reconstr Surg. 2012;129(5):1123-37.

78. Brommer H, Brama PAJ, Laasanen MS, Helminen HJ, van Weeren PR, Jurvelin JS. Functional adaptation of articular cartilage from birth to maturity under the influence of loading: a biomechanical analysis. Equine Vet J. 2005:37(2):148-54.

79. Kusuhara $H$, Isogai $N$, Enjo M, Otani $H$, Ikada $Y$, Jacquet $R$, et al. Tissue engineering a model for the human ear: assessment of size, shape, morphology, and gene expression following seeding of different chondrocytes. Wound Repair Regen. 2009;17(1):136-46.

80. Nabzdyk C, Pradhan L, Molina J, Perin E, Paniagua D, Rosenstrauch D. Auricular chondrocytes - from benchwork to clinical applications. In Vivo. 2009:23(3):369-80.

81. Homicz MR, Schumacher BL, Sah RL, Watson D. Effects of serial expansion of septal chondrocytes on tissue-engineered neocartilage composition. Otolaryngol Head Neck Surg. 2002;127:398-408.

82. Jian-Wei X, Randolph MA, Peretti GM, Nazzal JA, Roses RE, Morse KR, et al, Producing a flexible tissue-engineered cartilage framework using expanded polytetrafluoroethylene membrane as a pseudoperichondrium. Plastic Reconstr Surg. 2005;116(2):577-89.

83. Gonfiotti A, Jaus MO, Barale S, Baiguera S, Comin C, Lavorini F, et al. The first tissue-engineered airway transplantation: 5-year follow-up results. Lancet. 2014:383:238-44.

84. Delaere P, Vranckx J, Verleden G, De Leyn P, Van Raemdonck D. Tracheal Transplant Group. Tracheal allotransplantation after withdrawal of immunosuppressive therapy. N Engl J Med. 2010;362:138-45.

85. Vogel G. Trachea transplants test the limits. Science. 2013;340:266-8.

86. Ingber DE. Mechanical control of tissue growth: function follows form. Proc Natl Acad Sci U S A. 2005:102:11571-2.

87. Guillotin B, Guillemot F. Cell patterning technologies for organotypic tissue fabrication. Trends Biotechnol. 2011;29(4):183-90.

88. Birchall MA, Seifalian AM. Tissue engineering's green shoots of disruptive innovation. Lancet. 2014:384(9940):288-90.

89. Ma HL, Hung SC, Lin SY, Chen YL, Lo WH. Chondrogenesis of human mesenchymal stem cells encapsulated in alginate beads. J Biomed Mater Res A. 2003;64:273-81.

90. Li WJ, Tuli R, Huang X, Laquerriere P, Tuan RS. Multilineage differentiation of human mesenchymal stem cells in a three-dimensional nanofibrous scaffold. Biomaterials. 2005;26:5158-66.

91. Ho ST, Cool SM, Hui JH, Hutmacher DW. The influence of fibrin based hydrogels on the chondrogenic differentiation of human bone marrow stromal cells. Biomaterials. 2010;31:38-47.

92. Markway BD, Tan GK, Brooke G, Hudson JE, Cooper-White JJ, Doran MR. Enhanced chondrogenic differentiation of human bone marrow-derived mesenchymal stem cells in low oxygen environment micropellet cultures. Cell Transplant. 2010;19:29-42.

93. Dragoo JL, Samimi B, Zhu M, Hame SL, Thomas BJ, Lieberman JR, et al. Tissue-engineered cartilage and bone using stem cells from human infrapatellar fat pads. J Bone Joint Surg Br. 2003;85:740-7.

94. Betre H, Ong SR, Guilak F, Chilkoti A, Fermor B, Setton LA. Chondrocytic differentiation of human adipose-derived adult stem cells in elastin-like polypeptide. Biomaterials. 2006;27:91-9.

95. Cheng NC, Estes BT, Awad HA, Guilak F. Chondrogenic differentiation of adipose-derived adult stem cells by a porous scaffold derived from native articular cartilage extracellular matrix. Tissue Eng Part A. 2009;15:231-41.
96. Raghunath J, Sutherland J, Salih V, Mordan N, Butler PE, Seifalian AM. Chondrogenic potential of blood-acquired mesenchymal progenitor cells. J Plast Reconstr Aesthet Surg. 2010;63:841-7.

97. Dowthwaite GP, Bishop JC, Redman SN, Khan IM, Rooney P, Evans DJ, et al. The surface of articular cartilage contains a progenitor cell population. J Cell Sci. 2004;117(Pt 6):889-97.

98. Williams R, Khan IM, Richardson K, Nelson L, McCarthy HE, Analbelsi T, et al. Identification and clonal characterisation of a progenitor cell sub-population in normal human articular cartilage. PLoS One. 2010;5(10):e13246.

99. Kobayashi S, Takebe T, Zheng Y-W, Mizuno M, Yabuki Y, Maegawa J, et al. Presence of cartilage stem/progenitor cells in adult mice auricular perichondrium. PLoS One. 2011;6(10):e26393.

100. Kobayashi S, Takebe T, Inui M, Iwai S, Kan H, Zheng YW, et al. Reconstruction of human elastic cartilage by a CD44 CD90 stem cell in the ear perichondrium. Proc Natl Acad Sci U S A. 2011;108:14479.

101. Yanaga H, Imai K, Koga M, Yanaga K. Cell-engineered human elastic chondrocytes regenerate natural scaffold in vitro and neocartilage with neoperichondrium in the human body post-transplantation. Tissue Eng Part A. 2012;18(19-20):2020-9.

102. van Osch GJ, van der Veen SW, Burger EH, Verwoerd-Verhoef HL. Chondrogenic potential of in vitro multiplied rabbit perichondrium cells cultured in alginate beads in defined medium. Tissue Eng. 2000;6:321-30.

103. Bichara DA, Pomerantseva I, Zhao X, Zhou L, Kulig KM, Tseng A, et al. Successful creation of tissue-engineered autologous auricular cartilage in an immunocompetent large animal model. Tissue Eng A. 2014;20:303-12.

104. Xu JW, Zaporojan V, Peretti GM, Roses RE, Morse KB, Roy AK, et al. Injectable tissue-engineered cartilage with different chondrocyte sources. Plast Reconstr Surg. 2004;113:1361-71.

105. Isogai N, Asamura S, Higashi T, Ikada Y, Morita S, Hillyer J, et al. Tissue engineering of an auricular cartilage model utilizing cultured chondrocyte-poly(L-lactide-epsilon-caprolactone) scaffolds. Tissue Eng. 2004;10:673-87.

106. Semine AA, Damon A. Costochondral ossification and aging in five populations. Hum Biol. 1975;47(1):101-16.

107. Barchilon V, Hershkovitz I, Rothschild BM, Wish-Baratz S, Latimer B, Jellema $L M$, et al. Factors affecting the rate and pattern of the first costal cartilage ossification. Am J Forensic Med Pathol. 1996;17(3):239-47.

108. Lau AG, Kindig MW, Kent RW. Morphology, distribution, mineral density and volume fraction of human calcified costal cartilage. Acta Biomater. 2011;7(3):1202-9.

109. Zhou L, Pomerantseva I, Bassett EK, Bowley CM, Zhao X, Bichara DA, et al. Engineering ear constructs with a composite scaffold to maintain dimensions. Tissue Eng A. 2011;17(11-12):1573-81.

110. Romo 3rd T, Morris LG, Reitzen SD, Ghossaini SN, Wazen JJ, Kohan D. Reconstruction of congenital microtia-atresia: outcomes with the Medpor/bone-anchored hearing aid-approach. Ann Plast Surg. 2009:62(4):384-9.

111. Eyre DR, Dickson IR, Van Ness KP. Collagen cross-linking in human bone and articular cartilage. Age-related changes in the content of mature hydroxypyridinium residues. Biochem J. 1988;252:495-500.

112. Bank RM, Bayliss FPJG, Lafeber AM, Tekoppele J. Ageing and zonal variation in post-translational modification of collagen in normal human articular cartilage. Biochem J. 1998:330:345-51.

113. Williamson AK, Chen AC, Masuda K, Thonar EJ, Sah RL. Tensile mechanical properties of bovine articular cartilage: variations with growth and relationships to collagen network components. J Orthop Res. 2003:21(5):872-80

114. Zopf DA, Flanagan CL, Nasser HB, Mitsak AG, Huq FS, Rajendran V, et al. Biomechanical evaluation of human and porcine auricular cartilage. Laryngoscope. 2015;125(8):E262-8.

115. Khan IM, Evans SL, Young RD, Blain EJ, Quantock AJ, Avery N, et al. Fibroblast growth factor 2 and transforming growth factor $\beta 1$ induce precocious maturation of articular cartilage. Arthritis Rheum. 2011;63(11):3417-27.

116. Khan IM, Francis L, Theobald PS, Perni S, Young RD, Prokopovich P, et al. In vitro growth factor-induced bio engineering of mature articular cartilage. Biomaterials. 2013;34(5):1478-87.

117. Tseng A. Extensively expanded auricular chondrocytes form neocartilage in vivo. Cartilage. 2014:5:241-51.

118. Huey DJ, Sanchez-Adams J, Willard VP, Athanasiou KA. Immunogenicity of bovine and leporine articular chondrocytes and meniscus cells. Tissue Eng A. 2012;18(5-6):568-75. 
119. Sterodimas A, de Faria J. Human auricular tissue engineering in an immunocompetent animal model. Aesthet Surg J. 2013;33(2):283-9.

120. Markillie P. A third industrial revolution. 21 Apr 2012. http://www.economist. com/node/21552901. Accessed 9 Jan 2015.

121. Rozen WM, Ting JW, Baillieu C, Leong J. Stereolithographic modeling of the deep circumflex iliac artery and its vascular branching: a further advance in computed tomography-guided flap planning. Plast Reconstr Surg. 2012;130(2):380e-2e.

122. Gerstle TL, Ibrahim AMS, Kim PS, Lee BT, Lin SJ. A plastic surgery application in evolution: three-dimensional printing. Plast Reconst Surg. 2014;133(2):446-51.

123. Cohen A, Laviv A, Berman P, Nashef R, Abu-Tair J. Mandibular reconstruction using stereolithographic 3-dimensional printing modeling technology. Oral Surg Oral Med Oral Pathol Oral Radiol Endod. 2009;108(5):661-6.

124. Melchels F, Wiggenhauser PS, Warne D, Barry M, Ong FR, Chong WS, et al. CAD/CAM-assisted breast reconstruction. Biofabrication. 2011;3(3):034114

125. Wang G, Li J, Khadka A, Hsu Y, Li W, et al. CAD/CAM and rapid prototyped titanium for reconstruction of ramus defect and condylar fracture caused by mandibular reduction. Oral Surg Oral Med Oral Pathol Oral Radiol. 2012;113(3):356-61.

126. The world's first 3D printed total jaw reconstruction. June 2011. http://www. xilloc.com/patients/stories/total-mandibular-implant/. Accessed 9 Jan 2015.

127. Chrzan R, Urbanik A, Karbowski K, Moskała M, Polak J, Pyrich M. Cranioplasty prosthesis manufacturing based on reverse engineering technology. Med Sci Monit. 2012;18:MT1-6.

128. Manning L. Additive manufacturing used to create first laser-sintered cranial implant geometry. Adv Mater Processes. 2012;170(9):33-5.

129. Lee H, Ahn S, Bonassar L, Kim G. Cell(MC3T3-E1)-printed poly( $\epsilon$-caprolactone)/ alginate hybrid scaffolds for tissue regeneration. Macromol Rapid Commun. 2013;34(2):142-9.

130. Shim J-H, Kim JY, Park M, Park J, Cho DW. Development of a hybrid scaffold with synthetic biomaterials and hydrogel using solid freeform fabrication technology. Biofabrication. 2011;3(3):034102.

131. Visser J, Peters B, Burger TJ, Boomstra J, Dhert WJ, Melchels FP, et al. Biofabrication of multi-material anatomically shaped tissue constructs. Biofabrication. 2013;5(3):035007.

132. Xue J, Feng B, Zheng R, Lu Y, Zhou G, Liu W, et al. Engineering ear-shaped cartilage using electrospun fibrous membranes of gelatin/polycaprolactone. Biomaterials. 2013;34(11):2624-31.

133. Malda J, Visser J, Melchels FP, Jüngst T, Hennink WE, Dhert WJ, et al. 25th anniversary article: Engineering hydrogels for biofabrication. Adv Mater Weinheim. 2013;25(36):5011-28.

134. Guillemot F, Mironov V, Nakamura M. Bioprinting is coming of age: report from the International Conference on Bioprinting and Biofabrication in Bordeaux. Biofabrication. 2010;2(1):010201.

135. Catros S, Guillemot F, Nandakumar A, Ziane S, Moroni L, Habibovic P, et al. Layer-by-layer tissue microfabrication supports cell proliferation in vitro and in vivo. Tissue Eng C Methods. 2012;18(1):62-70.

136. Melchels FPW, Dhert WJA, Hutmacher DW, Malda J. Development and characterization of a new bioink for additive tissue manufacturing. J Mater Chem B. 2014;2(16):2282-9.

137. Censi R, Schuurman W, Malda J, Hennink WE. Printable photopolymerizable thermosensitive $\mathrm{p}$ (HPMA-lactate)-PEG hydrogel as scaffold for tissue engineering. Adv Funct Mater. 2011;21(10):1833-42.

138. Schuurman W, Khristov V, Pot MW, van Weeren PR, Dhert WJ, Malda J. Bioprinting of hybrid tissue constructs with tailorable mechanical properties. Biofabrication. 2011;3(2):021001.

139. Schuurman W, Levett PA, Pot MW, van Weeren PR, Dhert WJ, Hutmacher DW, et al. Gelatin-methacrylamide hydrogels as potential biomaterials for fabrication of tissue-engineered cartilage constructs. Macromol Biosci. 2013;13(5):551-61.

140. Xu T, Binder KW, Albanna MZ, Dice D, Zhao W, Yoo JJ, et al. Hybrid printing of mechanically and biologically improved constructs for cartilage tissue engineering applications. Biofabrication. 2013;5(1):015001.
141. Erickson IE, Kestle SR, Zellars KH, Farrell MJ, Kim M, Burdick JA, et al. High mesenchymal stem cell seeding densities in hyaluronic acid hydrogels produce engineered cartilage with native tissue properties. Acta Biomater. 2012;8(8):3027-34

142. Boere KMW, Visser J, Seyednejad H, Rahimian S, Gawlitta D, van Steenbergen MJ, et al. Covalent attachment of a 3D-printed thermoplast to a gelatin hydrogel for mechanically enhanced cartilage constructs. Acta Biomater. 2014;10(6):2602-11. 